\title{
HIDDEN IN PLAIN SIGHT: A NEW SPECIES OF PLEUROTHALLIS (ORCHIDACEAE: PLEUROTHALLIDINAE) FROM COLOMBIA PREVIOUSLY MISIDENTIFIED AS PLEUROTHALLIS LUCTUOSA
}

\author{
Mark Wilson ${ }^{1,4}$, Kehan ZhaO ${ }^{1}$, Hailey Hampson $^{1}$, Matt Chang ${ }^{1}$, \\ Guillermo A. ReInA-RodrígueZ ${ }^{2} \&$ ANDREA NiesSEN ${ }^{3}$
}

\author{
${ }^{1}$ Department of Organismal Biology and Ecology, Colorado College, Colorado Springs, \\ CO 80903, USA \\ ${ }^{2}$ Department of Geography, Universidad del Valle, Av. Pasoancho 100-00, Cali, Colombia \\ ${ }^{3}$ Orquídeas del Valle, Calle 10N \#9-31, Cali, Valle del Cauca, Colombia \\ ${ }^{4}$ Author for correspondence: mwilson@coloradocollege.edu
}

\begin{abstract}
Pleurothallis tenuisepala, a new species in subsection Acroniae, is described and compared to Pleurothallis luctuosa with which it has previously been confused. While the two species are superficially similar, they can be very easily distinguished by the size of the flowers, which are approximately $60 \mathrm{~mm}$ long in P. tenuisepala versus approximately $29 \mathrm{~mm}$ long in $P$. luctuosa, or the length of the sepals, which are approximately four-times the length of the petals in $P$. tenuisepala versus less than twice the length of the petals in P. luctuosa. The two species can also be discriminated by their nuclear internal transcribed spacer (nrITS) sequences. Pleurothallis tenuisepala occurs on Isla Gorgona off the Pacific coast of Colombia and on the western slopes of the Cordillera Occidental of the Colombian Andes, while P. luctuosa is restricted to the Cordillera de Tilarán of Costa Rica. Labellar micromorphology of both species is discussed in relation to possible pollination mechanisms.
\end{abstract}

RESUMEN. Se describe Pleurothallis tenuisepala, una nueva especie en la subseccción Acroniae, y se compara con Pleurothallis luctuosa, con la cual ha sido previamente confundida. Aunque las dos especies sean superficialmente similares, pueden ser fácilmente reconocidas por el tamaño de las flores, que miden aproximadamente $60 \mathrm{~mm}$ de longitud en $P$. tenuisepala versus cerca de $29 \mathrm{~mm}$ en $P$. luctuosa, así como por la longitud de los sépalos, que son aproximadamente cuatro veces más largos de los pétalos en $P$. tenuisepala, mientras que en $P$. luctuosa miden menos que el doble de los pétalos. Las dos especies pueden discriminarse también por las secuencias de su región espaciadora interna nuclear (nrITS). Pleurothallis tenuisepala se encuentra en la Isla Gorgona, frente a la costa pacífica de Colombia y en la vertiente occidental de la Cordillera Occidental de los Andes colombianos, mientras que P. luctuosa está restringida a la Cordillera de Tilarán de Costa Rica. Se discute la micromorfología del labelo de ambas especies en relación a posibles mecanismos de polinización.

KeY wORDS / PALABRAS CLAVE: Acroniae, cryptic species, especies crípticas, labellum, morfología, morphology, taxonomía, taxonomy

Introduction. According to Pupulin et al. (2010), Pleurothallis luctuosa was described by Reichenbach (1877) from a plant in the collection of the botanical garden at the University of Hamburg, Germany, which was presumed to have been collected by Endrés in Costa Rica. Illustrations by Reichenbach (Fig. 1A) and Endrés (Figs. 1B-C) undoubtedly represent the same species found in the Cordillera de Tilarán in northwest Costa Rica, illustrated (Fig. 1D) in Pupulin et al. (2010). The flowers of P. luctuosa are pink-purple in coloration, sometimes with yellow at the apices of the sepals and petals; have sepals slightly less than twice the length of the petals; and have a yellow-green, scutate or shield-shaped lip (Fig. 2B).

Collections of plants identified as Pleurothallis luctuosa exhibit a suspiciously disjunct distribution, coming from northwest Costa Rica and Nicaragua in Central America and from southwest Colombia and northwest Ecuador in South America (Luer 1998, Viveros \& Higgins 2007, Tropicos 2019), but without any records from the intervening country of Panama, or from northwest Colombia. Luer (1998) illustrated one of these collections from Pichincha, Ecuador in his monograph of subsection Acroniae. The species illustrated has sepals more than twice the length of 
TABLE 1. Accessions of Pleurothallis luctuosa and Pleurothallis tenuisepala,

\begin{tabular}{l|l|c|c} 
Accession/voucher & Species & Origin & $\begin{array}{c}\text { GenBank Accession } \\
\text { Number for nrITS }\end{array}$ \\
\hline PL0071 & P. luctuosa & Tropical Orchid Farm & MN240885 \\
\hline PL0327 & P. luctuosa & Tropical Orchid Farm & MN240886 \\
\hline PL0426 & P. luctuosa & JBL11663, Jardín Botánico Lankester & MN240887 \\
\hline PL0427 & P. luctuosa & JBL10449, Jardín Botánico Lankester & MN240888 \\
\hline PL0428 & P. luctuosa & JBL10438, Jardín Botánico Lankester & MN240889 \\
\hline PL1010 & P. luctuosa & Andy's Orchids & MN240890 \\
\hline PL1011 & P. luctuosa & Andy's Orchids & MN240891 \\
\hline PL0963 & P. tenuisepala & Orquídeas del Valle & MN240875 \\
\hline PL1038 & P. tenuisepala & Atlanta Botanic Gardens (Orquídeas del Valle) & MN240876 \\
\hline
\end{tabular}

the petals and a distinctly hastate or triangular lip which is clearly different from the scutate lip of $P$. luctuosa. Pupulin et al. (2010) suggested that the species illustrated by Luer (1998) as P. luctuosa might instead be an undescribed species.

The disjunct distribution, combined with the morphologic variation in the Ecuadorian form noted by Pupulin et al. (2010), suggested to us that all South American collections might have been misidentified as Pleurothallis luctuosa. To investigate the possibility that one or more so-called "cryptic" species has been included among South American specimens previously identified as P. luctuosa, in this first study, plant material from Colombia was compared to P. luctuosa from Costa Rica. Here we report on the results of this comparison; demonstrate that the Colombian material is distinct both morphologically and genetically from $P$. luctuosa; and describe the Colombian collections as a new species of Pleurothallis in subsection Acroniae.

\section{Materials and Methods}

Plant material.- Plants sold as Pleurothallis luctuosa were purchased from Orquídeas del Valle, Cali, Colombia (PL0963); from Tropical Orchid Farm, Hawaii, USA (PL0071 and PL0327); and from Andy's Orchids, California, USA (PL1010 and PL1011) (Table 1). All plants were accessioned into the living collection in the greenhouse at Colorado College and those which flowered during the study period were vouchered with flowers preserved in spirits. In addition to the living plant material, tissue for DNA was obtained from three accessions of $P$. luctuosa from Jardín Botánico Lankester, Cartago, Costa Rica (PL0426, PL0427, PL0428); and from a plant labeled as P. luctuosa at the Atlanta Botanic Gardens, Atlanta, Georgia, USA, which originated from Orquídeas del Valle, Colombia (PL1038) (Table 1).

Morphological and taxonomic comparisons.- The Colombian species was compared morphologically with the holotype of Pleurothallis luctuosa at the herbarium of the Vienna Natural History Museum, Vienna, Austria (W); with the drawings of P. luctuosa by Reichenbach (Fig. 1A), Endrés (Fig. 1B-C) and Pupulin (Fig. 1D) (Pupulin et al. 2010); and with living material of P. luctuosa at Colorado College. To confirm uniqueness, the species was also compared with all Pleurothallis species published in subsection Acroniae since the Luer (1998) monograph (Luer 1999, Luer 2009, 2011, Pupulin et al. 2010, Luer \& Thoerle 2012, 2013, Doucette et al. 2017).

The Colombian species additionally was compared with collections labeled as Pleurothallis luctuosa, but suspected to be misidentified, from the herbaria at the Marie Selby Botanical Gardens, FL, USA (SEL); the Smithsonian National Museum of Natural History, Washington DC, USA (US); the herbarium of Jardín Botánico José Celestino Mutis (JBB); and with unidentified collections of Pleurothallis from the herbarium at the Universidad del Valle, Cali, Colombia (CUVC).

Scanning electron microscopy.- Flowers of the Colombian species and of Pleurothallis luctuosa from the Colorado College living plant collection were prepared for and examined by scanning 

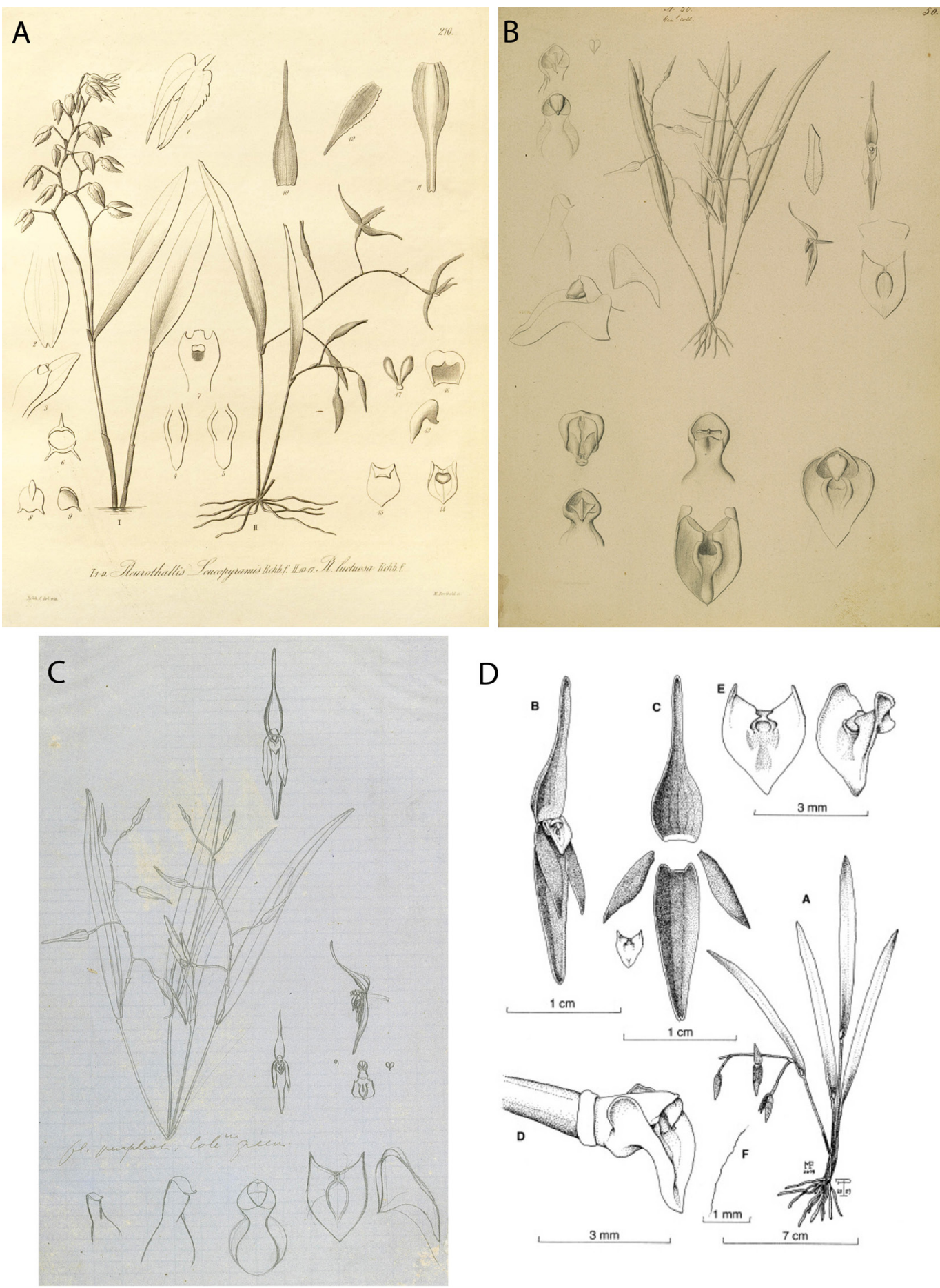

Figure 1. A. Pleurothallis luctuosa drawing by H. G. Reichenbach (drawings II 10-17). (Plate 210 from Kränzlin 1900.$)$; B. P. luctuosa drawing by A. R. Endrés (W 0020308). C. P. luctuosa drawing by A. R. Endrés (W 0020306). D. P. luctuosa drawing. a. Whole plant. b. Whole flower. c. Dissected flower. d. Column and lip. e. Lip, front view and $3 / 4$ view. f. Margin of petal. (From Pupulin et al. 2010) (B, C and D courtesy of Vienna Natural History Museum). 


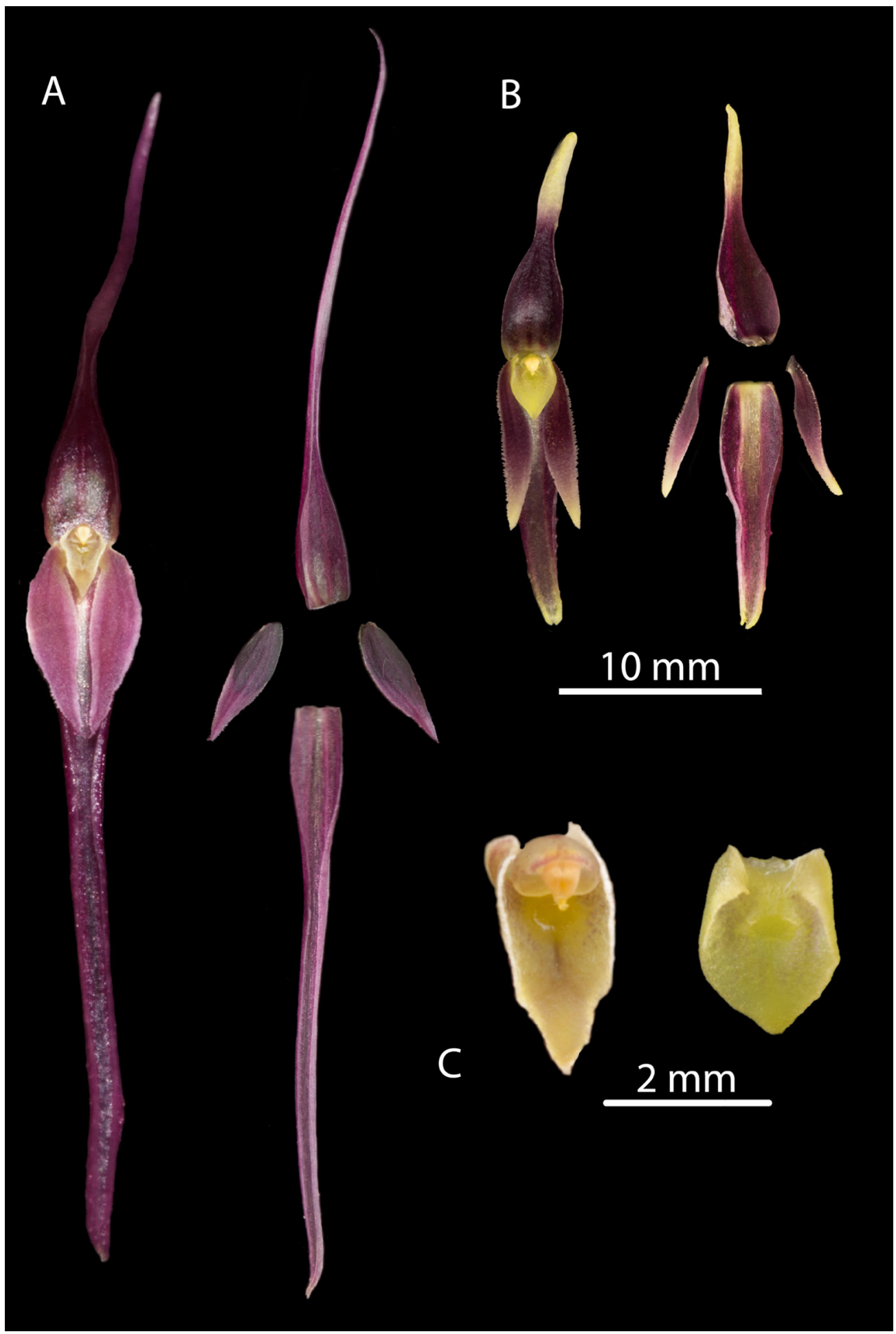

Figure 2. A. Pleurothallis tenuisepala whole flower and perianth; B. Pleurothallis luctuosa whole flower and perianth; C. Lips of P. tenuisepala and P. luctuosa. (Prepared by Mark Wilson from P. tenuisepala PL0963 and P. luctuosa PL0071.) 
TABle 2. Comparison of dimensions of Pleurothallis luctuosa and Pleurothallis tenuisepala.

\begin{tabular}{l|c|c} 
& $\begin{array}{c}\text { Pleurothallis luctuosa } \\
\text { (from Pupulin et al. 2010) }\end{array}$ & Pleurothallis tenuisepala \\
\hline Whole flower & $\sim 29 \mathrm{~mm}$ long & $\sim 60 \mathrm{~mm}$ long \\
\hline Dorsal sepal & $\begin{array}{c}15 \times 4 \mathrm{~mm} \\
5 \text {-veined }\end{array}$ & $\begin{array}{c}29.0 \times 2.8 \mathrm{~mm} \\
3-\text { veined }\end{array}$ \\
\hline Synsepal & $\begin{array}{c}14 \times 4 \mathrm{~mm} \\
3-\mathrm{veined}\end{array}$ & $\begin{array}{c}29.0 \times 2.8 \mathrm{~mm} \\
4-\mathrm{veined}\end{array}$ \\
\hline Petals & $8 \times 2 \mathrm{~mm}$ & $7 \times 2 \mathrm{~mm}$ \\
\hline Sepal/petal ratio & 1.9 & 4.1 \\
\hline Column & $1.0 \mathrm{~mm}$ & $1.7 \mathrm{~mm}$ \\
\hline Labellum (unexpanded) & $3.5 \times 1.5 \mathrm{~mm}$ & $2.8 \times 1.2 \mathrm{~mm}$
\end{tabular}

electron microscopy (SEM). Fresh-harvested flowers were preserved in Kew Mix (5\% formalin $[37.6 \%$ formaldehyde], $53 \%$ methanol, $5 \%$ glycerol, $37 \%$ deionized water). Flowers were dehydrated in successively higher concentrations of ethanol $(80 \%$, $95 \%, 100 \%, 100 \%$ ) for $15 \mathrm{~min}$ each before being placed in freshly-opened $100 \%$ ethanol. Specimens were dried in a critical point dryer (model EMS 850, Electron Microscopy Sciences, Hatfield, PA, USA) prior to mounting on aluminum stubs and sputter coating (model Pelco SC-6, Ted Pella, Redding, CA, USA). Specimens were imaged using a scanning electron microscope (model JSM-6390LV, Jeol, Peabody, MA, USA) with an accelerating voltage of $10-15 \mathrm{kV}$.

DNA sequence comparisons.- The Colombian species was compared genetically with the samples of Pleurothallis luctuosa acquired from Costa Rica and the living plant material at Colorado College. The nuclear internal transcribed spacer (nrITS) region was sequenced for the two accessions of the Colombian species (PL0963 and PL1038); for three samples of P. luctuosa from Jardín Botanico Lankester (PL0426, PL0427 and PL0428); and for four accessions of $P$. luctuosa from Colorado College (PL0071, PL0327, PL1010 and PL1011) (Table 1).

Genomic DNA was extracted from fresh material ground under liquid nitrogen using a DNeasy Plant Mini Kit (QIAGEN, USA). The nrITS region was amplified using the primer pair 17SE and 26SE (Sun et al. 1994) and the PCR product was purified using a QIAquick Gel Extraction Kit (QIAGEN, USA). The gel-purified PCR products were sequenced at GeneWiz
(New Jersey, USA). Forward and reverse sequences were edited and aligned in geneious R11 (geneious. com) and a 765 bp consensus sequence generated. All nrITS sequences were uploaded to GenBank (Table 1). The nrITS sequences of Pleurothallis luctuosa and the Colombian species were aligned and compared in geneious.

\section{Results}

Morphological comparisons.- The Colombian species (Fig. 2A) differs significantly from Pleurothallis luctuosa (Fig. 2B): the flower is much larger, approximately $60 \mathrm{~mm}$ long compared to approximately $29 \mathrm{~mm}$ long; and the ratio of sepal-to-petal length is much higher, approximately four-times the length versus less than twice the length (Table 2). The lips are also different in shape, being hastate in the Colombian species versus scutate in P. luctuosa (Fig. 2C). In scanning electron micrographs, the scutate lip of $P$. luctuosa exhibits a distinct glenion in the mesochile, surrounded by a raised, hippocrepiform or horseshoeshaped callus with the gap in the horseshoe towards the apex of the lip and a short, shallow sulcus extending towards the apex (Fig. 3-5). In contrast, in the more hastate or triangular lip of the Colombian species the glenion it is set further back under the column in the hypochile region; the prominent callus is absent; and a longer, deeper sulcus extends forward from the glenion into the mesochile of the lip (Fig. 3-5).

DNA sequence comparisons.- The nrITS sequence of Pleurothallis luctuosa starting at CGG GCG GTT and ending at CCA CCC G was 765 bp in length. When aligned in geneious R11 the seven P. luctuosa sequences 

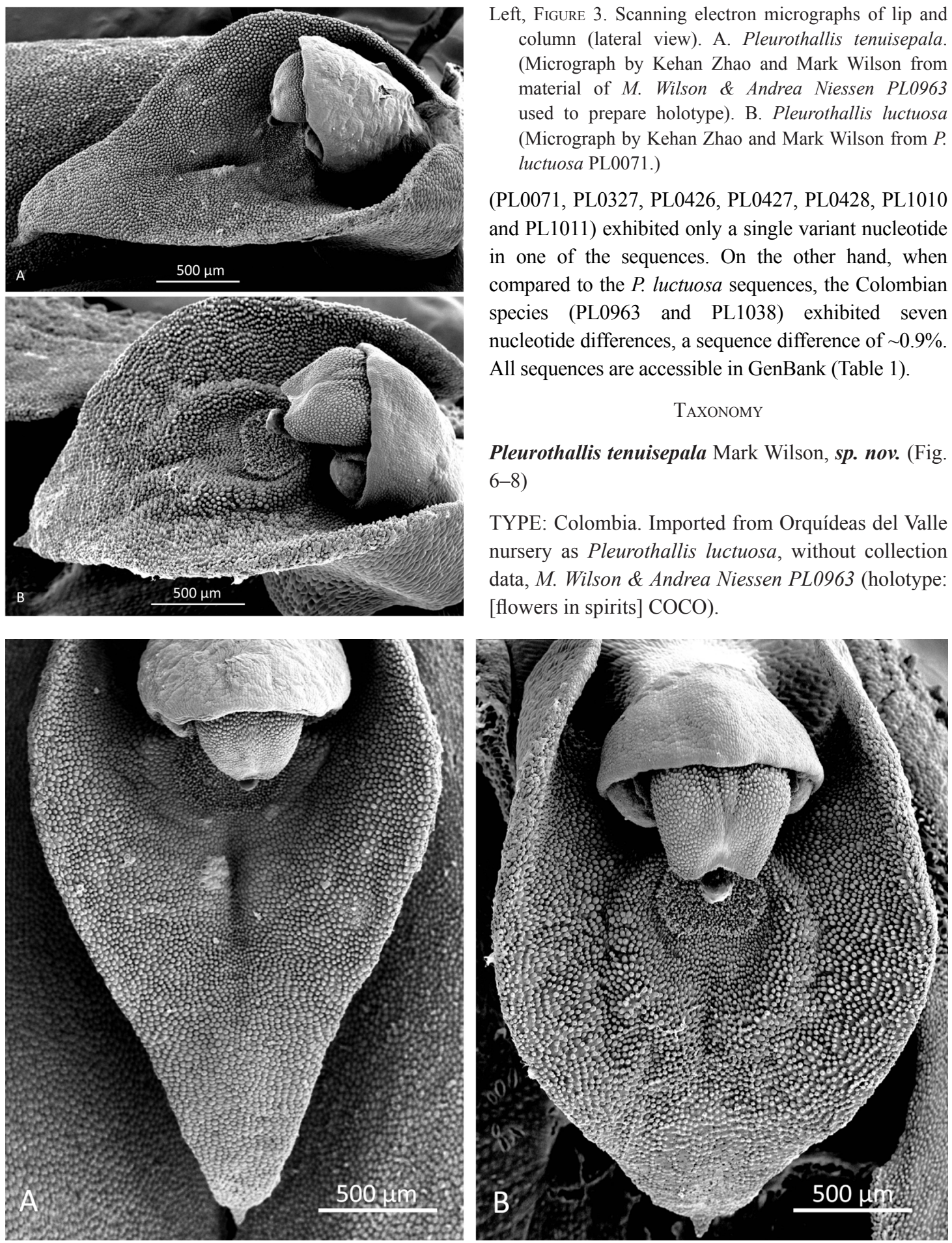

FIgURE 4. Scanning electron micrographs of lip (dorsal view). A. Pleurothallis tenuisepala. (Micrograph by Kehan Zhao,

Hailey Hampson and Mark Wilson from material of M. Wilson \& Andrea Niessen PL0963 used to prepare holotype). B.

Pleurothallis luctuosa (Micrograph by Kehan Zhao and Mark Wilson from P. luctuosa PL0071.) 

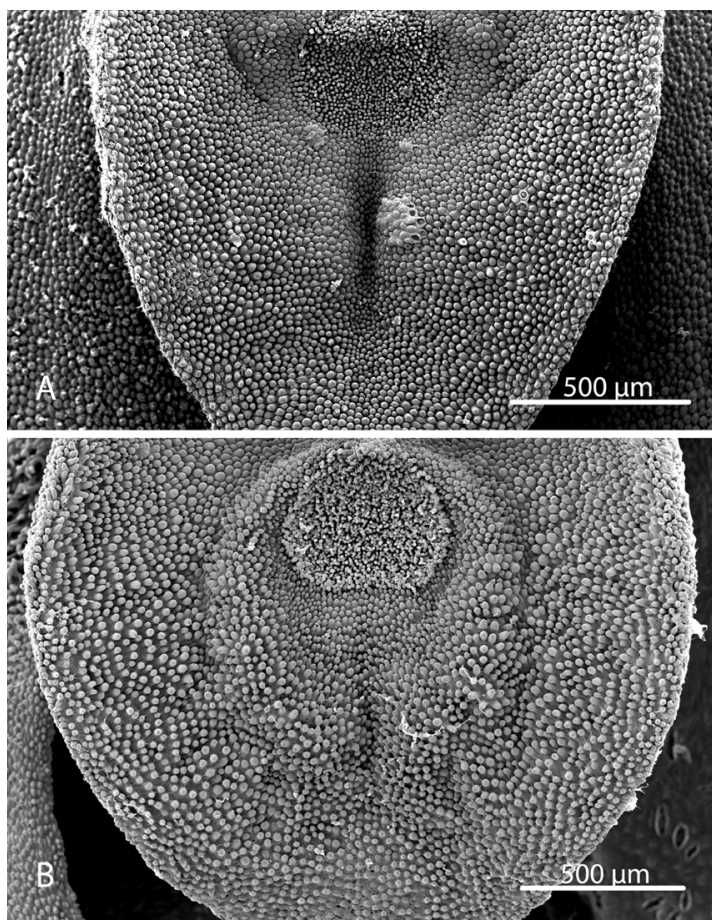

FIGURE 5. Scanning electron micrographs of lip and glenion (dorsal view). A. Pleurothallis tenuisepala. (Micrograph by Kehan Zhao, Hailey Hampson and Mark Wilson from material of M. Wilson \& Andrea Niessen PL0963 used to prepare holotype). B. Pleurothallis luctuosa (Micrograph by Kehan Zhao and Mark Wilson from $P$. luctuosa PL0071.)

This species can be distinguished from Pleurothallis luctuosa by: the size of the flowers (approximately $60 \mathrm{~mm}$ in length in Pleurothallis tenuisepala versus approximately $29 \mathrm{~mm}$ in $P$. luctuosa); the relative length of the sepals and petals (sepals approximately four-times the length of the petals in P. tenuisepala versus less than twice in P. luctuosa); and by the shape of the lip (hastate with moderately deep medial sulcus below the glenion in P. tenuisepala versus scutate with horseshoe-shaped callus surrounding the glenion in P. luctuosa).

Plant small to medium, to $\sim 15 \mathrm{~cm}$ tall, epiphytic, caespitose. Roots slender, fibrous, densely fasciculate. Ramicauls suberect, slender, terete, 2.4-5.5 cm long, enclosed near the base by a papyraceous sheath, 10-19 $\mathrm{mm}$ long. Leaves suberect to spreading, narrowly ovatelanceolate, acute, minutely mucronate, base sessile, cuneate, 7.6-10.2 × 1.0-1.4 cm, coriaceous, channeled along midrib. Inflorescence arching, distichous, few (4-6)-flowered raceme, $\sim 8 \mathrm{~cm}$ long, emerging from a reclining spathaceous bract at leaf base, 4-7 mm long, peduncle $2.7 \mathrm{~cm}$ long, rachis internode $1.4 \mathrm{~cm}$ long, floral bract tubular, membranous, $4.6 \mathrm{~mm}$ long, pedicel $10.8 \mathrm{~mm}$ long. Ovary pale green, $3.0-3.3 \mathrm{~mm}$ long. Flower $\sim 60 \mathrm{~mm}$ from tip of dorsal sepal to tip of synsepal. Dorsal sepal pale purple, lanceolate, concave at base, edges involute toward apex, glabrous, 3-veined, $29 \times 2.8 \mathrm{~mm}$. Synsepal pale purple, toward apex, lanceolate, concave at base, edges involute toward apex, glabrous, 4-veined, $29 \times 2.8 \mathrm{~mm}$. Petals pale purple, ovate-subfalcate, acuminate, 3 -veined, $7 \times$ $2 \mathrm{~mm}$, glabrous, margin irregularly dentate. Labellum pale yellow-green lightly suffused with purple, $\sim 2.8 \times$ $1.2 \mathrm{~mm}$ (unexpanded), tri-lobed, central lobe with basal glenion, shallow channel above glenion, tip apiculate, curved, basal lobes clasping the column, margins irregular. Column pale yellow-green lightly suffused with purple, stout, $1.5-1.7 \times 0.6 \mathrm{~mm}$, subapical anther, bilobed stigma, short column foot. Pollinarium two obovate yellow pollinia, $0.50 \times 0.18 \mathrm{~mm}$. Capsule unknown.

Additional material studied: Colombia. Cauca. Parque Nacional Natural Gorgona. D. Mora 0009, 16th December, 2018 (CUVC-spirit!). Colombia. Cauca. Parque Nacional Natural Gorgona. Killip and Garcia 33162, 1939 (US!). Colombia. Flowered in cultivation at Marie Selby Botanical Gardens without collection data apart from country, F.L.Stevenson 61874-14, 2nd October, 1975 (SEL!). Colombia. Cauca. Popayán from collection of Amalia Lehmann, flowered in cultivation at Colomborquídeas, Medellin, Colombia, C.Luer 17556, 23rd May 1995 (SEL!). Colombia. Cauca. Road between Uribe and Quebradito, Km. 81, 2200 m, cultivated by Amalia Lehmann in Popayán, C.Luer 8180, 21st October 1982 (SEL!). (Note: The location "Quebradito" does not exist in the area of Popayán and is probably a mistake, the correct location likely being Quebradillas, López de Micay, Cauca.) Confiscated from the farm of JB-JCM. Unknown origin. Juan Camilo Ordóñez Blanco JACOB 1394, 20th February 2012 (JBB!). Colombia. Grown in cultivation, but thought to have been collected near Santa Cecilia, Risaralda, Carlos Uribe Velez, April 2019 (HPUJ 29767).

Eтymology: Pleurothallis tenuisepala for the delicate, graceful, narrow sepals. 
A

C

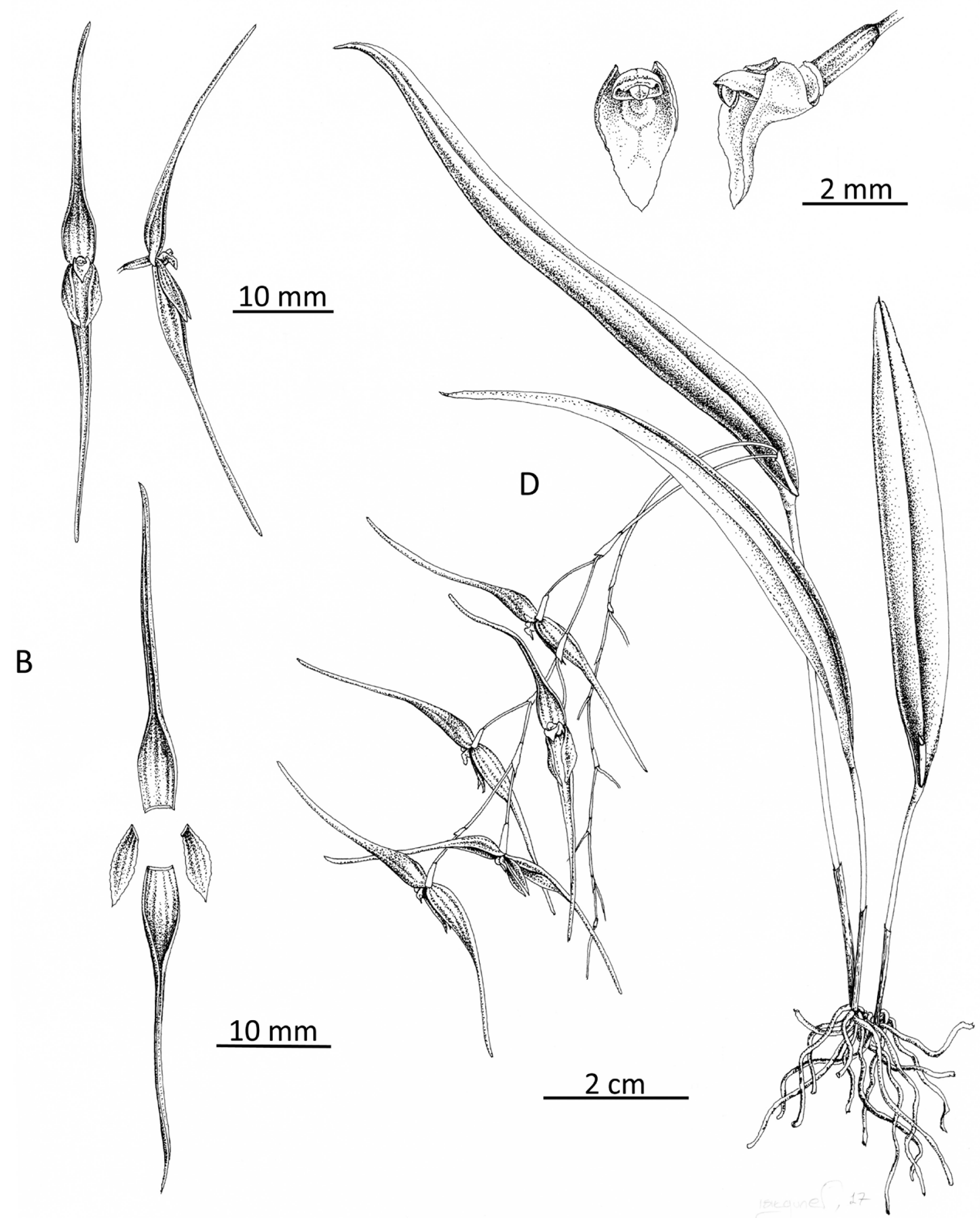

Figure 6. Pleurothallis tenuisepala drawing. A. Whole flower front and side view. B - Dissected flower. C. Lip and column, front view and $3 / 4$ views. D. Whole plant. (Drawing by Ișik Güner from material of M. Wilson \& Andrea Niessen PL0963 used to prepare holotype.) 


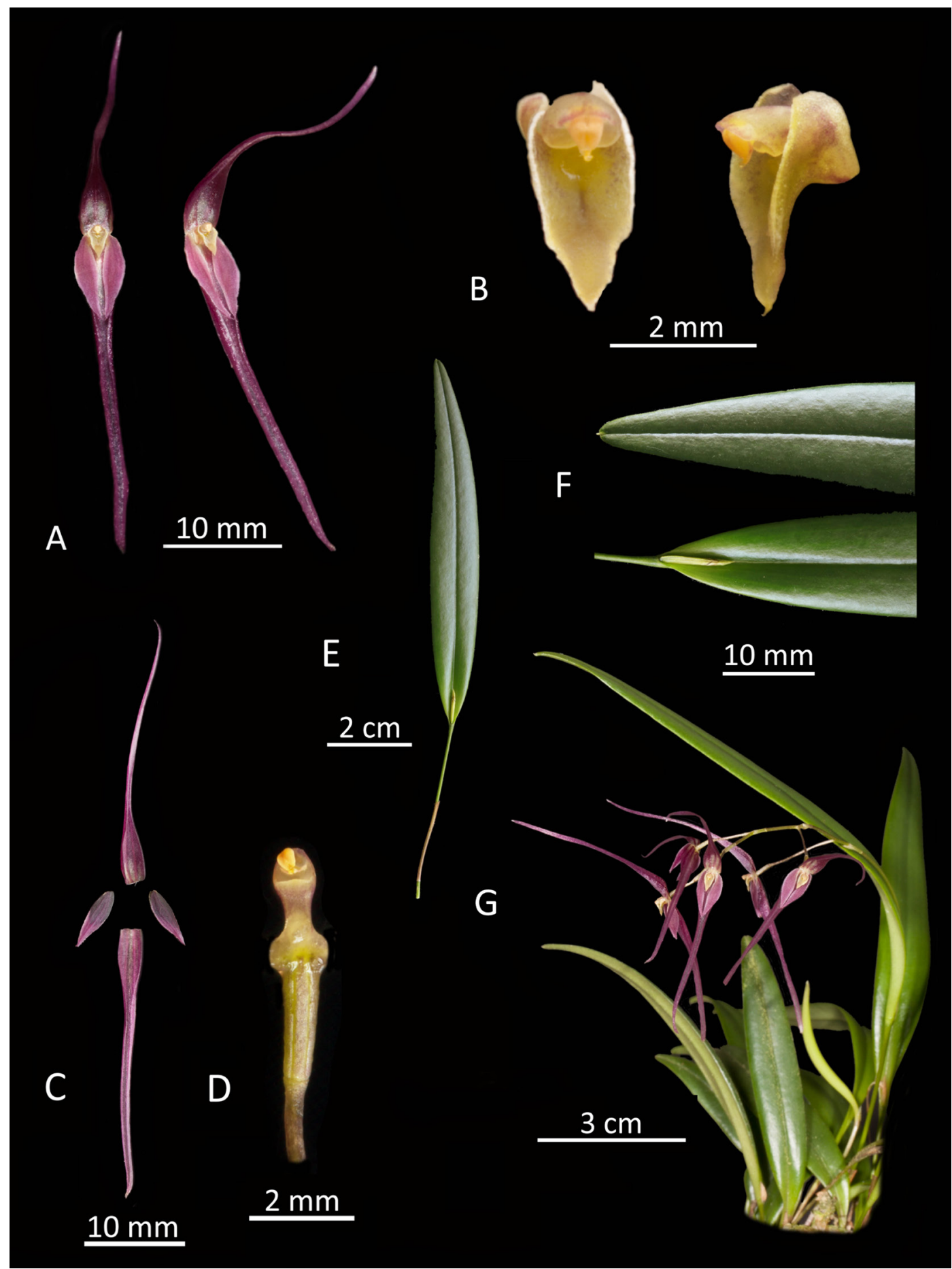

FIgure 7. Pleurothallis tenuisepala Lankester composite dissection plate (LCDP). A. Whole flower, front and three quarters views. B. Lip and column, front and $3 / 4$ views; C. Dissected flower. D. Column and ovary, ventral view. E. Whole leaf; F. Leaf, apex and base. G. Whole plant with inflorescence. (Prepared by Mark Wilson from material of M. Wilson \& Andrea Niessen PL0963 used to prepare holotype.) 


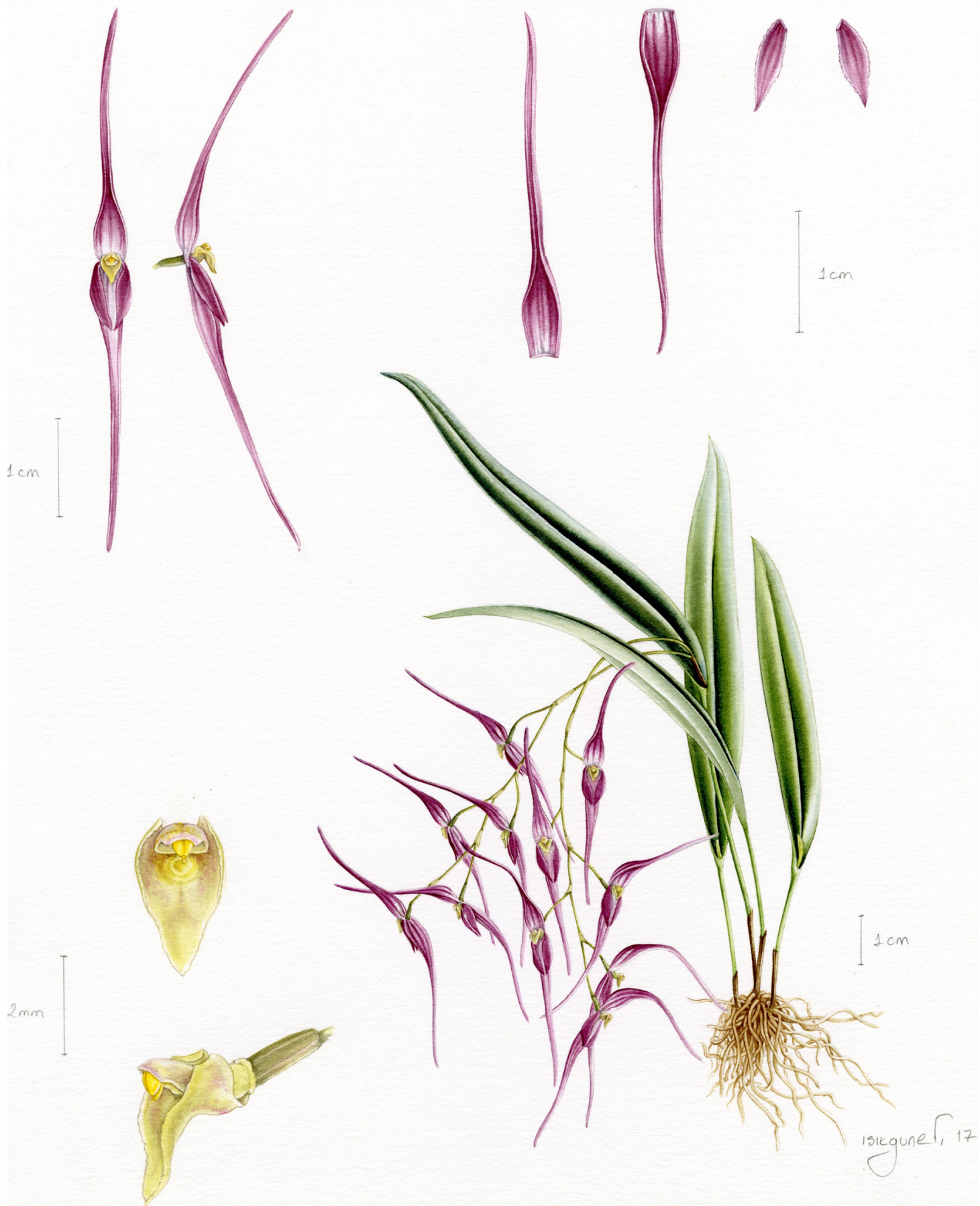

Figure 8. Pleurothallis tenuisepala water color painting. (Painting by Ișik Güner from material of M. Wilson \& Andrea Niessen PL0963 used to prepare holotype.) 
DistriBution AND HABITAT: As far as we know, Pleurothallis tenuisepala was first collected from the Parque Nacional Natural (PNN) Gorgona, an island off the Pacific coast of Cauca, Colombia, by Killip and Garcia on February 11th, 1939 (US 1770144; Fig. 9) at an elevation of 50-100 $\mathrm{m}$ in dense forest along a stream. It was collected again in PNN Gorgona by Mora in 2018. However, it has also been collected from the road between Quebradillas and Uribe, northwest of Popayán, Cauca, Colombia at an elevation of 2200 $\mathrm{m}$, on the Pacific slope of the Cordillera Occidental. This distribution and elevation range are somewhat surprising and future molecular examination of multiple samples from each location may reveal distinct genotypes corresponding to elevational ecotypes. These two locations may represent relict populations of what was previously a much more widely distributed species at intermediate elevations in forest that has now been destroyed.

Conservation status: While the Pacific lowland forests of the Chocó biogeographic region have experienced high levels of deforestation, the populations of Pleurothallis tenuisepala in PNN Gorgona are presumed secure at this time, having been observed recently. It is unknown, however, whether the higher elevation population from northwest of Popayán, which may represent a distinct ecotype of $P$. tenuisepala, still exists. It is possible that the species is extant within the boundaries of the nearby Parque Nacional Natural Munchique. Until further information on distribution and abundance can be obtained $P$. tenuisepala should be considered data deficient (DD) according to IUCN criteria.

Discussion. Although previously misidentified, Pleurothallis tenuisepala from Cauca, Colombia is very easily distinguished from the Costa Rican species Pleurothallis luctuosa based on floral morphology. How then could such a misidentification occur? Vegetatively the species are indeed very similar and both produce lax racemes of pale purplish flowers. It is likely that Luer had not seen living material of P. luctuosa in Costa Rica when, presumably in comparison to the drawings by Reichenbach and Endrés, or to the type material, he concluded that the Ecuadorian species was $P$. luctuosa. A drawing under that name was included in Icones Plantarum Tropicarum series I (plate 242 Dodson et al. 1980). Then, in 1991, upon examination of the material from PNN Gorgona collected by Killip and Garcia, presumably due to the similarity with the Ecuadorian material, Luer identified this Colombian specimen to also be P. luctuosa (Fig. 9). Subsequently, the use of the P. luctuosa drawing from Icones Plantarum Tropicarum in the monograph on subsection Acroniae (Luer 1998) cemented the belief that the species in Ecuador and Colombia were P. luctuosa, that is until the identification was questioned by Pupulin et al. (2010).

We agree with Pupulin et al. (2010) that the species identified by Luer as Pleurothallis luctuosa from Santo Domingo de Las Tsáchilas, Ecuador (Dodson et al. 1980, Luer 1998) is not P. luctuosa. We cannot yet conclusively say whether the Ecuadorian species is distinct from the Colombian Pleurothallis tenuisepala, though preliminary analyses suggest that it is and that the Ecuadorian material represents a distinct species. Studies of herbarium collections and living material of this species are ongoing at this time and will be published in a separate paper.

To date, Pleurothallis tenuisepala has been collected from only two confirmed locations in the Department of Cauca, Colombia: in PNN Gorgona, on Isla Gorgona, an island off the Cauca coast; and on the Pacific slope of the Cordillera Occidental near the eastern border of Parque Nacional Natural Munchique, northwest of Popayán, Cauca. The species was also photographed and collected some time ago and has been maintained in cultivation by Uribe Velez and is thought to have come from near Santa Cecilia, Pueblo Rico, Risaralda, Colombia (Ortiz Valdivieso \& Uribe Velez 2007, Uribe Velez, pers. comm.). Other than Cauca, and possibly Risaralda, we found no evidence that $P$. tenuisepala has been collected from any other Colombian Departments. While the species may historically have had a wider distribution in the lowland and midelevation forests of the Pacific slopes of the Andean Cordillera Occidental of Colombia, part of the Chocó biogeographic region, the only recently confirmed locality is that on Isla Gorgona. To our knowledge, $P$. luctuosa does not occur in Colombia and collections in herbaria identified as $P$. luctuosa from southwest Colombia are in fact all $P$. tenuisepala.

Contemporary disjunct species distributions, like 


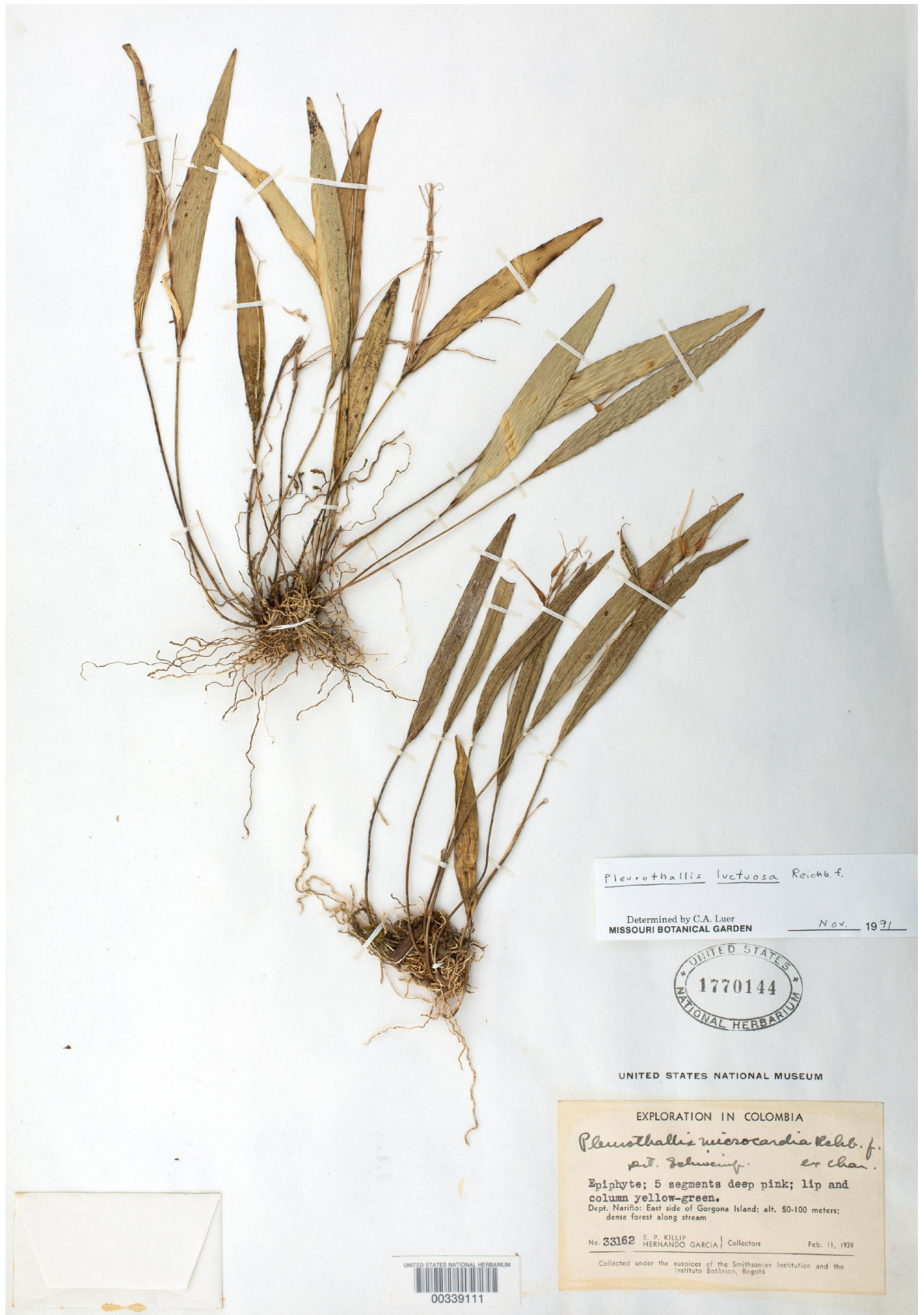

FIGURE 9. Pleurothallis tenuisepala collection Killip and Garcia 33162 (US 1770144) from Isla Gorgona with identification by Luer in 1991 as Pleurothallis luctuosa. (Courtesy herbarium of the Smithsonian National Museum of Natural History.) 
that exhibited by collections labeled Pleurothallis luctuosa from Costa Rica and Colombia, are not necessarily indicative of the presence of undescribed, so-called "cryptic", species. Relatively recent anthropogenic disturbances such as deforestation may have resulted in the extirpation of intervening populations or the intervening areas may have been poorly collected. However, in this instance, the morphological differences combined with the geographic separation indicate that Pleurothallis tenuisepala is distinct from P. luctuosa. This example further reinforces that Pleurothallis species characterized as widely-distributed and morphologically variable, particularly those with disjunct distributions, should be examined closely for the presence of cryptic species. Within Pleurothallis, such studies have already revealed new species in the Pleurothallis crocodiliceps Rchb.f. complex (Wilson et al. 2017a); the Pleurothallis cardiothallis Rchb.f. complex (Pupulin et al. 2017a); and the Pleurothallis phyllocardia Rchb.f. complex (Pupulin et al. 2017b). Priorities for future examination of widely-distributed, morphologically variable species include: Pleurothallis bivalvis Lindl., Pleurothallis cordata Lindl., Pleurothallis lilijae Foldats and Pleurothallis microcardia Rchb.f., each of which seems to consist of multiple entities (Luer 2005).

In addition to the morphological differences and the disjunct distribution, Pleurothallis tenuisepala and Pleurothallis luctuosa exhibited an approximately $0.9 \%$ difference in nrITS sequences ( 7 nucleotides out of 765 bp). Several other authors working in the Pleurothallidinae have utilized sequence data to support the description of new species (Meyer et al. 2012, Ramos-Castro et al. 2012, Karremans et al. 2015). However, there is no accepted minimum percentage sequence difference in nrITS between so-called "sister" species in Pleurothallidinae (Karremans et al. 2015), nor can there be, since different lineages have evolved at different rates. In a discussion of genetic differences between sister species in Pleurothallidinae, Karremans et al. (2015) suggest that nrITS sequences may vary from $\sim 0.25 \%$ between the sister species Specklinia dunstervillei Karremans, Pupulin and Gravend. and Specklinia endotrachys (Rchb.f.) Pridgeon \& M.W.Chase up to $\sim 1 \%$ between Specklinia marginata (Lindl.) Pridgeon \& M.W.Chase and Specklinia sp. This would place the difference between P. tenuisepala and P. luctuosa at the upper end of that range, thereby providing additional support for the contention that these are distinct species.

Returning to morphology, Luer (1986) coined the term "glenion", from the Greek glene, for "socket or eyeball" (Luer, pers. comm.), for the small, often circular, area of differentiated tissue on the hypochile of the labellum, under the gynostemium or column. Luer (1986) commented that the glenion was often "shiny or sticky" and opined that "undoubtedly it plays a part in attracting pollinators". Using SEM, Wilson et al. (2016) examined the glenion of Pleurothallis nangaritzae M.M.Jiménez, Tobar \& Mark Wilson and Pleurothallis rubrifolia Mark Wilson, Tobar \& Salas Guerr. of subsection Macrophyllae-Fasciculatae. They hypothesized that the glenion "acts not just to attract the pollinator but that it serves to position the pollinator in the optimal position for pollinarium acquisition or deposition." Wilson et al. (2018) further noted that the vast majority of species in subsection Macrophyllae-Fasciculatae possess such a glenion. In SEM micrographs of the labellum of Pleurothallis caucensis Mark Wilson, from subsection Macrophyllae-Racemosae, Wilson et al. (2017b) observed a deposit resembling dried liquid partially covering the glenion and the subtending sulcus. Sandoval Mojica (2018) sampled the secretions from the lip of Pleurothallis coriacardia Rchb.f. and found these secretions to consist of $\sim 13 \%$ sugar. These observations taken together lead us to hypothesize that the glenion, along with other areas of the Pleurothallis lip, secrete a liquid, sugar-based pollinator attractant/reward essential to the pollination process.

In SEM micrographs, the labella of both Pleurothallis tenuisepala and Pleurothallis luctuosa both exhibit a glenion. The glenion of $P$. tenuisepala consists of loosely-packed columnar or papillose cells, surrounded by a region of densely-packed cells forming a slightly raised callus. The glenion is subtended by a sulcus which we hypothesize allows a liquid reward from the glenion to flow by either capillary action or gravity into the mesochile region to act as a pollinator attractant/reward. The glenion of $P$. luctuosa similarly consists of loosely-packed papillose cells, but instead is surrounded by a distinctly raised, hippocrepiform callus. A very shallow sulcus subtends the opening in the callus and, again, we hypothesize that a liquid reward flows from the glenion into the sulcus, providing an attractant/reward to position the pollinator optimally for pollinarium acquisition or deposition. Studies 
are ongoing to address the hypothesis that the glenion in Pleurothallis acts as a "nectary" producing a sugarcontaining, nectar-like pollinator attractant/reward in subsections Acroniae, Macrophyllae-Fasciculatae and Macrophyllae-Racemosae; and, further, that the presence of a glenion and production of a pollinator reward is the ancestral state in subgenus Pleurothallis.

In addition to these studies on labellar morphology and secretions, future studies in the Acroniae will examine the species from Santo Domingo, Pichincha, Ecuador, to determine whether it is distinct from Pleurothallis tenuisepala and will investigate the phylogenetic relationships between P. tenuisepala, Pleurothallis sp. "Santa Domingo" and the other members of the Central and South American subsection Acroniae.
ACKNOWLEDGEMENTS. The authors are grateful to Colorado College for research funding for Wilson, Chang, Hampson and Zhao and for provision of greenhouse, laboratory, herbarium and electron microscopy facilities; to Robert Hevey for financial support for Zhao; to Ron Hathaway for assistance with SEM; to Franco Pupulin for providing material of P. luctuosa; to Andy Phillips of Andy's Orchids and Kevin Holcomb of Atlanta Botanic Gardens for plant material; to Carlos Uribe Velez for species distribution information and preparing a herbarium specimen from his material; to Néstor García of HPUJ for receiving a specimen of $P$. tenuisepala from Uribe Velez; to Toscano de Brito for scans of SEL herbarium specimens; and to the Editors of Lankesteriana and the anonymous reviewers for extremely helpful suggestions to improve the manuscript.

\section{LiteratuRe Cited}

Dodson, C. H., Dodson, P. M., Vásquez, R., Hamer, F., Mora, D. E., Atwood, J. \& Bennet, D. E. (1980). Icones Plantarum Tropicarum, Series I, Fascicle 2. Sarasota, Florida: The Marie Selby Botanical Gardens.

Doucette, A., Portilla, J., Medina, H. \& Cameron, K. (2017). A new species of Pleurothallis (Orchidaceae: Pleurothallidinae) from Ecuador. Phytotaxa, 295(2), 194-198.

Karremans, A. P., Pupulin, F. \& Gravendeel, B. (2015). Specklinia dunstervillei, a new species long confused with Specklinia endotrachys (Orchidaceae: Pleurothallidinae). PLoS ONE, 10(7), e0131971.

Luer, C. A. (1986). Icones Pleurothallidinarum III: Systematics of Pleurothallis. Monographs in Systematic Botany, 20, $1-109$.

Luer, C. A. (1998). Icones Pleurothallidinarum XVII: Systematics of subgen. Pleurothallis sect. Abortivae, sect. Truncatae, sect. Pleurothallis, subsect. Acroniae, subsect. Pleurothallis, subgen. Dracontia, subgen. Unciferia. Monographs in Systematic Botany from Missouri Botanical Garden, 72, 1-121.

Luer, C. A. (1999). Nuevas especies de Pleurothallis de Colombia. Orquideología, 21(2), 115-134.

Luer, C. A. (2005). Icones Pleurothallidinarum XXVII: Dryadella and Acronia section Macrophyllae-Fasciculatae. Monographs in Systematic Botany from Missouri Botanical Garden, 103, 1-311.

Luer, C. A. (2009). Miscellaneous new species in the Pleurothallidinae (Orchidaceae). Selbyana, 30(1), 1-71.

Luer, C. A. (2011). Miscellaneous new species in the Pleurothallidinae (Orchidaceae) excluding species from Brazil. Harvard Papers in Botany, 16(2), 311-360.

Luer, C. A. \& Thoerle, L. (2012). Miscellaneous new species in the Pleurothallidinae (Orchidaceae). Harvard Papers in Botany, 17(2), 333-369.

Luer, C. A. \& Thoerle, L. (2013). Miscellaneous new species in the Pleurothallidinae (Orchidaceae). Harvard Papers in Botany, 18(2), 173-196.

Meyer, G., Baquero, L. \& Cameron, K. M. (2012). A new Ecuadorian species of Dracula: Pleurothallidinae (Orchidaceae). Orchideen Journal, 19, 107-113.

Ortiz Valdivieso, P. \& Uribe Velez, C. (2007). Galería de orquídeas de Colombia. CD. Bogotá, Colombia: Da Vinci Editores.

Pérez-Escobar, O. A., Chomicki, G., Condamine, F. L., Karremans, A. P., Bogarín, D., Matzke, N. J., Silvestro, D. \& Antonelli, A. (2017). Recent origin and rapid speciation of Neotropical orchids in the world's richest plant biodiversity hotspot. New Phytologist, 215, 891-905.

Pridgeon, A. M., Solano, R. \& Chase, M. W. (2001). Phylogenetic relationships in Pleurothallidinae (Orchidaceae): Combined evidence from nuclear and plastid DNA sequences. American Journal of Botany, 88, 2286-2308.

Pupulin, F., Bogarín, D. \& Fernández, M. (2010). Illustrations and studies in Neotropical orchids. 2. A note on Pleurothallis luctuosa (Orchidaceae: Pleurothallidinae), with a new species. Annalen des Naturhistorischen Museums in Wien, B, $112,1-14$.

Pupulin, F., Díaz-Morales, M., Aguilar, J. \& Fernández, M. (2017a). Two new species of Pleurothallis (Orchidaceae: 
Pleurothallidinae) allied to P. cardiothallis, with a note on flower activity. Lankesteriana, 17(2), 329-356.

Pupulin, F., Díaz-Morales, M., Fernández, M. \& Aguilar, J. (2017b). Two new species of Pleurothallis (Orchidaceae: Pleurothallidinae) from Costa Rica in the P. phyllocardia group. Lankesteriana, 17(2), 153-164.

Ramos-Castro, S. E., Castañeda-Zárate, Solano-Gómez, R. \& Salazar, G. A. (2012). Stelis zootrophionoides (Orchidaceae: Pleurothallidinae), a new species from Mexico. PLoS ONE, 7(11), e48822.

Reichenbach, H. G. (1877). Pleurothallis luctuosa. Linnaea, 41, 48.

Sandoval Mojica, A. C. (2018). Aspectos de la biología floral y visitantes florales de Lepanthes monoptera Lindl. y Pleurothallis coriacardia Rchb.f. (Pleurothallidinae: Orchidaceae) dos especies de orquídeas epífitas en la Reserva Forestal Protectora El Malmo. Tesis, Universidad Pedagógica y Tecnológica de Colombia, Tunja.

Sun, Y., Skinner, D. Z., Liang, G. H. \& Hulbert, S. H. (1994). Phylogenetic analysis of Sorghum and related taxa using internal transcribed spacers of nuclear ribosomal DNA. Theoretical and Applied Genetics, 89, 26-32.

Tropicos. (2019). Tropicos. Missouri Botanical Garden, Missouri, USA. Retrieved on March $2^{\text {nd }} 2019$ from http://www. tropicos.org/Home.aspx

Viveros, P. \& Higgins, W. E. (2007). Checklist of Pleurothallidinae from Colombia. Selbyana, 28(1), 13-90.

Wilson, M., Baquero, L., Dupree, K., Jiménez, M. M., LeBlanc, C. M., Merino, G., Portilla, J., Salas Guerrero, M., Tobar Suárez, F. \& Werner, J. D. (2016). Three new species of Pleurothallis (Pleurothallidinae; Orchidaceae) in subsection Macrophyllae-Fasciculatae from northern South America. Lankesteriana, 16(3), 349-366.

Wilson, M., Dupree, K., Driessen, W., Larsen, B. T., Löckher, A., Niessen, A., Portilla, J., Salas Guerrero, M., Suarez, M. A. \& Tobar Suárez, F. (2017a). A clarification of the taxonomy of Pleurothallis crocodiliceps Rchb.f. (Pleurothallidinae, Orchidaceae) and four new species of Pleurothallis in subgenus Ancipitia. Lankesteriana, 17(2), 165-191.

Wilson, M., Dupree, K., Garcia Lopera, D., Haelterman, D., Kay, A., Mesa Londoño, C., Niessen, A., Pinnix, W., Portilla, J. \& Werner, J. (2017b). A new species of Pleurothallis (Orchidaceae: Pleurothallidinae) from Valle del Cauca, Colombia and a note on the relationship between subsections Macrophyllae-Racemosae and Antenniferae. Lankesteriana, 17(2), $119-131$.

Wilson, M., Zhao, K., Hampson, H., Frank, G., Romelroux, K., Jiménez, M. M., Tobar, F., Larsen, B. \& Pérez, A. (2018). A new species of Pleurothallis (Orchidaceae: Pleurothallidinae) in subsection Macrophyllae-Fasciculatae with a unique, highly reduced, morphologically distinct labellum. Lankesteriana, 18(3), 217-230. 
